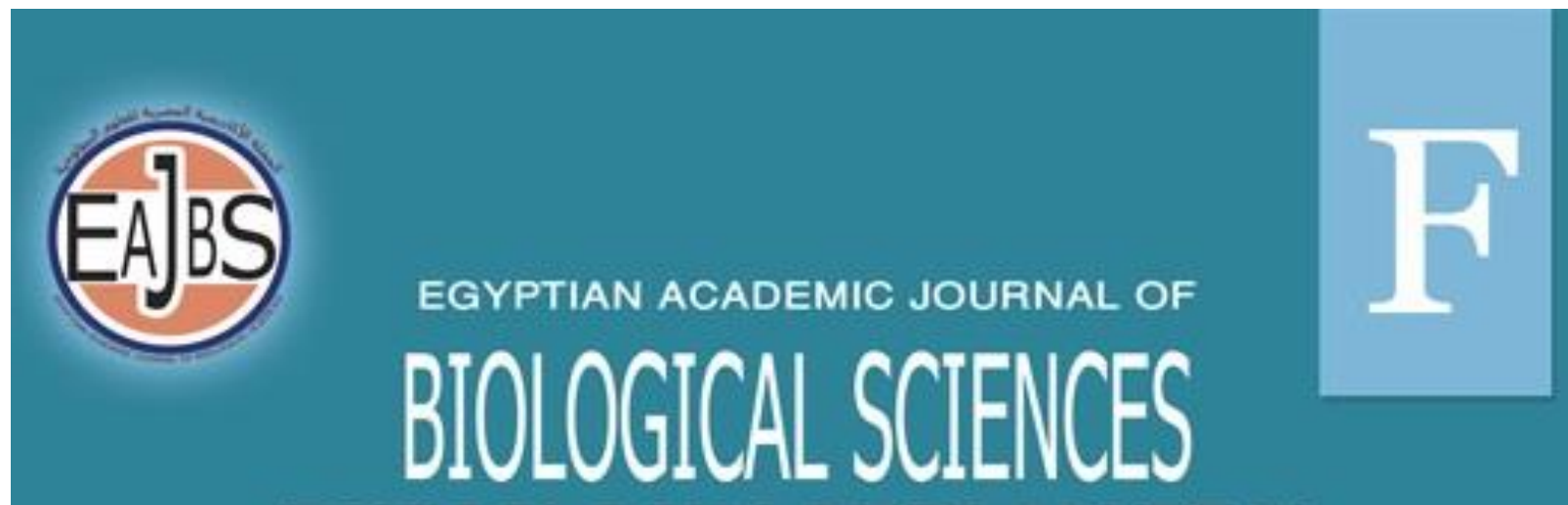

TOXICOLOGY \& PEST CONTROL

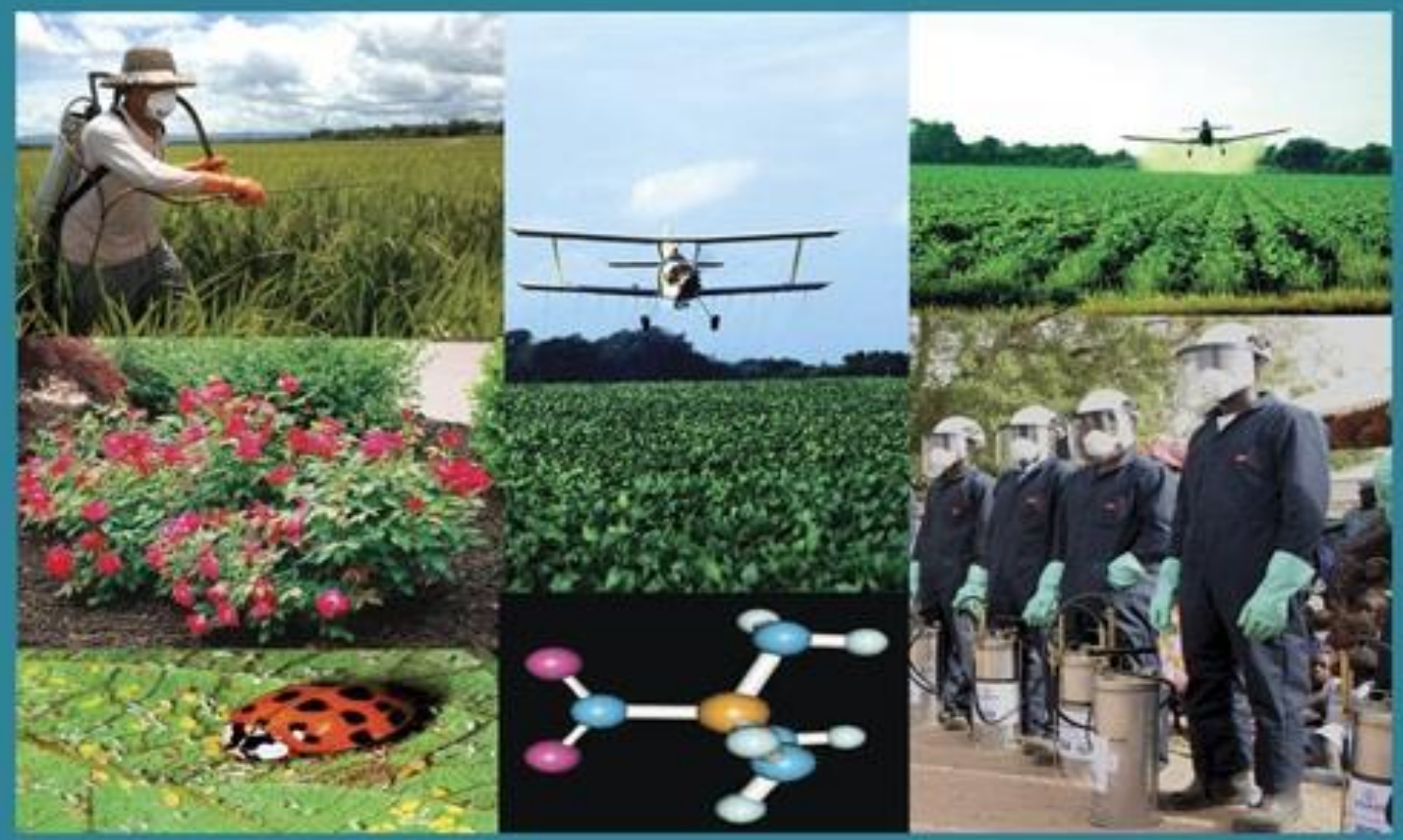

ISSN

2090-0791

WWW.EAJBS.EG.NET

Vol. 13 No. 1 (2021)

$\underline{\text { www.eajbs.eg.net }}$

Citation :Egypt. Acad. J. Biolog. Sci. (F.Toxicology \& Pest control) Vol.13(1)pp159-176(2021)

DOI: 10.21608/EAJBSF.2021.153353 
Egypt. Acad. J. Biolog. Sci., 13(1):159- 176 (2021)

Egyptian Academic Journal of Biological Sciences

F. Toxicology \& Pest Control

ISSN: 2090 - 0791

http://eajbsf.journals.ekb.eg/

\title{
Potential Effect of the Nematicide Oxamyl and Surfactant Combinations on Root- Knot Nematode Meloidogyne incognita Infecting Tomato Plants
}

\author{
Abdelhadi A. I. Ali and Ramadan M. El-Ashry \\ Department of Plant Protection, Faculty of Agriculture, Zagazig University, Egypt. \\ *E-Mail : aaalai@agri.zu.edu.eg
}

\section{ARTICLEINFO}

Article History

Received: 2/12/2020

Accepted: 3/3/2021

\section{Keywords:}

Agrimax-3H, Silwet L-77, Sylgard 309, oxamyl, Meloidogyne incognita, rootknot nematodes, tomato

\section{ABSTRACT}

The adjuvants involved in pesticide formulation have a vital role in enhancing the physical properties of active ingredient delivered to the target site in plant-parasitic nematodes. The present study elucidates the potential effect of combinations of the nematicide oxamyl (Vaydate $^{\circledR} 24 \%$ SL) and surfactants on the root-knot nematode Meloidogyne incognita infecting tomato plants. Three surfactants namely, Agrimax-3 $\mathrm{H}^{\circledR}$, Silwet L-77 ${ }^{\circledR}$, and Sylgard $309^{\circledR}$ were used at their recommended rats $(15 \mathrm{ml} / 100 \mathrm{~L}, 5 \mathrm{ml} / 100 \mathrm{~L}$, and $250 \mathrm{ml} / 100 \mathrm{~L}$, respectively) as well as the combinations of their respective $1 / 4 \mathrm{R}, 1 / 2 \mathrm{R}$, $3 / 4 \mathrm{R}$ with oxamyl at three rates i.e. the recommended ( $\mathrm{R}, 48 \mathrm{mg}$ a.i /plant); 3/4 R, $36 \mathrm{mg}$ a.i./plant and $1 / 2 \mathrm{R}, 24 \mathrm{mg}$ a.i./plant.

The results revealed that surfactants caused approximately 50 and $25 \%$ hatching inhibition in egg masses and eggs, respectively while oxamyl exhibited the highest egg hatching inhibition by $90 \%$ throughout the trial period. The combination of oxamyl and Agrimax3H showed significantly $(P \leq 0.01)$ more effectiveness against egg masses $(71.17 \%)$ or free eggs $(55.45 \%)$ hatching as exposure time increase. Moreover, oxamyl potency increased to kill $95 \%$ of $\mathrm{IJ}_{2}$ whereas, other surfactants caused a $30 \%$ reduction. The mixtures of all tested adjuvants with oxamyl at the recommended rate raised oxamyl potency to kill $100 \% \mathrm{IJ}_{2}$ accompanied by a shortage of oxamyl latent period (LP). Whereas, Agrimax-3H surpassed other surfactants and shorted the $\mathrm{LT}_{50}$ of oxamyl to 0.82 days increasing its nematicidal effect. The addition of surfactants to oxamyl as protective treatment displayed a significant increase in tomato plant growth and suppressed galling of $M$. incognita while the combination between oxamyl and surfactants as curative treatments showed a vigor control efficacy within oxamyl and Agrimax-3H only and surpassed oxamyl formulation without significant difference.

\section{INTRODUCTION}

Root-knot nematodes (Meloidogyne spp.) are the main soil-borne disease especially in hot climates or short winters and considered the most damaging nematodes in agriculture, causing an estimated $\$ 100$ billion loss/year worldwide (Oka et al., 2000). Nowadays, Meloidogyne spp. ranked at the top among the five major plant pathogens and the first among the ten most important genera of plant-parasitic nematodes in the world (Ravichandra, 2014). 
More than 2000 plants worldwide are susceptible to root-knot nematodes infection (Sasser et al., 1975) comprised a wide range of crops i.e. field crops, pastures, grasses, horticultural, ornamental and vegetable crops (Stirling et al., 1995). Globally, more than 27\% of yield losses in tomato (Sharma and Sharma, 2015) resulted from root-knot nematode disease. Infection in young plants may be lethal or results in poor growth, while infection of mature plants causes yield reduction and decline in quality and yield of the crop.

Nearly one hundred valid species are in the genus Meloidogyne (Trinh et al., 2019). The most destructive species is $M$. incognita (Kofoid and White) Chitwood which causes serious damage to most crops worldwide (Moens et al., 2009). The thinking tuned directly to soil drenching application with chemical nematicides and may be ends with soil sterilization with fumigants to achieve fast-acting and considerable results in plant-parasitic nematodes control. The root-knot nematodes disease development requires taking a quick curative action to stop epidemic infection for crops using chemical nematicides e.g. carbofuran, fenamiphos, fensulfothion, and oxamyl (Taylor, 2003). However, there are many reports concerned with contamination of groundwater and different food types with aldicarb residues (Tchounwou et al., 2002). But taking this risk is necessary to keep the plants almost intact until the end of the crop season. Intra-season, nematodes could be controlled using soil sterilization or rebuilt/ enhance soil biodiversity by introducing microbial biocontrol agents to guaranteed sustainability and prevent epidemic soilborne diseases in the future. Wise and rationalized chemical nematicides consumption is required to improve the active gradient of nematicides to control plant-parasitic nematodes and target site with a suitable amount enough to increase the toxic effect efficiently.

Following application, less than $0.1 \%$ of recommended nematicides reach their target. while, more than $99.9 \%$ of nematicide used to release in the environment (Pimentel, 1995). Applied chemical pesticides directly to a target pest (plant or animal) caused contamination of crop plants, soil organisms, potentially, humans, and wildlife in the immediate area as well as, air or surface waters due to emission or drift. The persistence and the bio-efficiency of the pesticide depend on its physical and chemical properties (partition coefficients, degradation rates, deposition rates) and the characteristics of the environment (Health Canada, 1998). The main target of pesticide formulation is changing the physical properties of active ingredients to improve the delivered amount of active ingredient reached to the target pest. The additional inert component in the formulation is called adjuvants which can be classified as a premix or a tank mix based on combination time.

Therefore, the present study aimed to determine the effect of three tank-mix adjuvants on oxamyl (Vydate ${ }^{\circledR} 24 \%$ SL) application rate as well as their efficiency against the development and reproduction of root-knot nematode, $M$. incognita infecting tomato plants under greenhouse conditions in vivo.

\section{MATERIALS AND METHODS}

\section{The Nematicide and Surfactants Used:}

The Vydate ${ }^{\circledR} 24 \%$ SL is the commercial formulation of oxamyl, registered and available in the market, applied against different phytonematodes in Egypt, with a rate of 0.2 $\mathrm{ml} / \mathrm{plant}, 12.5 \mathrm{~kg} / \mathrm{fed}$. The tested formulation was obtained from the Central Laboratory of Pesticides, Dokki, Giza.

The tested surfactants included: Agrimax $-3 \mathrm{H}^{\circledR}$ [(excellent adhesive) alkylated vinyl pyrrolidone polymers which alkyl groups are grafted surfactant and polymer properties combined polymeric surfactant], Silwet L- $77^{\circledR}$ [(organosilicon nonionic surfactant) is distributed by Loveland (Greeley, CO, USA)] and Sylgard $309^{\circledR}$ (organosilicon nonionic surfactant) are distributed by Wilbur-Ellis (Fresno, CA, USA). 
The labeled recommended rates of the three mentioned surfactants are $15 \mathrm{ml} / 100 \mathrm{~L}, 5 \mathrm{ml}$ $/ 100 \mathrm{~L}$, and $250 \mathrm{ml} / 100 \mathrm{~L}$, respectively.

\section{Culturing of the Root-Knot Nematode, Meloidogyne incognita:}

The pure culture of $M$. incognita was isolated and maintained in the greenhouse on susceptible tomato cultivar "Super Strain B" as a source of inoculum. The species identification was verified based on the juvenile measurements and examination of the perineal pattern system of adult females according to Jepson, (1987).

\section{Preparation of Egg Masses, Eggs and Second-Stage Juveniles:}

Infected tomato roots were cut into pieces of $2 \mathrm{~cm}$ long and placed in a $600 \mathrm{ml} \mathrm{flask}$ with $200 \mathrm{ml}$ of $0.5 \%$ sodium hypochlorite ( $180 \mathrm{ml}$ water $+20 \mathrm{ml}$ Clorox $)$. The tightly capped flack was shaken for 3 minutes. The shaking partially dissolved the gelatinous matrix thus freeing eggs from egg masses (Hussey and Barker, 1973). The liquid suspension of eggs was poured through a 200 mesh sieve nested upon a 500 mesh sieve. Eggs collected on the 500 mesh sieve were immediately washed free of residual sodium hypochlorite solution under a slow stream of tap water and incubated in Petri dishes at $25 \pm 2{ }^{\circ} \mathrm{C}$ until hatching. Newly hatched juveniles were collected by using a micropipette. Egg masses of equal size needed to study the effect of the tested surfactants on $M$. incognita egg hatching were handpicked with fine forceps from small galls on the infected tomato roots obtained from previously maintained pure culture. The collected egg masses were surface sterilized in a 1:500 v/v aqueous solution of sodium hypochlorite for 5 min (Whitehead and Hemming, 2008).

\section{In vitro Treatments:}

The tested combination treatments consisted of surfactant at the recommended rate $(\mathrm{R}), 1 / 2 \mathrm{R}$ oxamyl $+1 / 2 \mathrm{R}$ Surfactant, $3 / 4 \mathrm{R}$ oxamyl $+1 / 4 \mathrm{R}$ Surfactant and the recommended rate of oxamyl. Distilled water was used as a negative control treatment.

1. The Influence Of Various Combinations Of Surfactants And Oxamyl On Egg Masses, Egg Hatching Inhibition And Juveniles Mortality:

\section{A-Egg Masses:}

Five fresh and uniform size egg masses were transferred to $10 \mathrm{~cm}$ diameter Petri dishes containing $10 \mathrm{ml}$ of the above-mentioned treatments. Each treatment was replicated five times. All treatments were incubated at $25 \pm 2{ }^{\circ} \mathrm{C}$. The number of hatched juveniles was counted using a research microscope (100X magnification). The cumulative number of hatched juveniles in each Petri dish was counted at 2, 4, 7, 10 and 14 days post-treatment. The percentage of hatchability inhibition was calculated according to the following equation:

Egg hatching inhibition (\%) $=\frac{\text { No. of hatched juveniles in Control }- \text { No. of hatched juveniles in Treatment }}{\text { No. of hatched juveniles in Control }} \times 100$

\section{B- Free Eggs:}

Free eggs of $M$. incognita were extracted from infected tomato roots using the method described by Hussey and Barker (1973) as mentioned before. Extracted eggs were suspended in distilled water and counted by using a counting slide under a research microscope (100X magnification). The number of eggs per $1 \mathrm{ml}$ was adjusted to about 1000 eggs by diluting the suspension. Approximately 100 nematode eggs in $0.1 \mathrm{ml}$ of water were exposed to $10 \mathrm{ml}$ of the tested treatments. The Petri dishes were kept at $25 \pm 2^{\circ} \mathrm{C}$ for 14 days. The percentage of hatchability inhibition was calculated as mentioned above.

\section{C- Juveniles Mortality:}

The suspension concentration of second-stage juveniles $\left(\mathrm{IJ}_{2}\right)$ was adjusted to $1000 \mathrm{IJ}_{2} / \mathrm{ml}$, then $0.1 \mathrm{ml}$ suspension $\left(\approx 100 \mathrm{IJ}_{2}\right)$ was complemented to $10 \mathrm{ml}$ volume of the above-mentioned treatments. The negative control treatment comprised $100 \mathrm{IJ}_{2}$ in $(0.1 \mathrm{ml})$ complemented to $10 \mathrm{ml}$ sterile distilled water. All treatments were kept at $25 \pm 2{ }^{\circ} \mathrm{C}$. Each treatment was replicated five times. The $\mathrm{IJ}_{2}$ mortality was observed at $1,3,5$ and 7 days under $100 \mathrm{X}$ magnification in $1 \mathrm{ml}$ over the specified periods. The $\mathrm{IJ}_{2}$ showing inactive 
straight posture or did not show any movement after probing were considered dead (Ishibashi and Takii, 1993; Nardo and Grewal, 2003). Immobile $\mathbf{I J}_{2}$ were collected, then washed with distilled water and allowed to recover in distilled water for $5 \mathrm{~h}$. The mortality percentages were calculated from the following equation:

\section{In vivo experiments:}

$$
\text { Mortality }(\%)=\frac{\text { No. of dead juveniles }}{\text { Total number of juveniles }} \times 100
$$

\section{Impact of Oxamyl and Surfactant Treatments on Galling and Reproduction of $M$. Incognita Infecting Tomato Under Greenhouse Conditions:}

The greenhouse experiments were implemented based on the timing of tested combinations application and inoculation:

\section{A. Prophylactic (Protective) Treatment:}

The tomato plant was chosen because it is severely attacked by the root-knot nematode, $M$. incognita as well as its regional economic importance. Tomato seedlings Solanum lycopersicum L. cv. 016 (20 days old) were transplanted in $15 \mathrm{~cm}$ diameter- plastic pots $(1$ seedling/pot) containing steam-sterilized sandy soil $(93.5 \%$ sand; $1.4 \%$ silt; $5.1 \%$ clay). When tomato seedlings were approximately $10 \mathrm{~cm}$ in height, they were inoculated with 1000 newly hatched IJs of $M$. incognita per plant. The inoculum was obtained from available pure culture formerly prepared and propagated in the greenhouse. The IJs were added by pipetting $2 \mathrm{ml}$ of the inoculum suspension into three holes around the root system, then covered with moist soil and $10 \mathrm{ml}$ of the tested combination were added immediately after inoculation.

The experiment was conducted in a $4 \times 4$ factorial experiment with a complete randomized block design with five replicates. The treatments consisted of combinations of the recommended rate of the surfactants Agrimax-3H, Silwet L-77 and Sylgard 309 with oxamyl at $0.5,0.75$ and 1.0 of its recommended rate besides surfactant and oxamyl free treatments. An addition check treatment included healthy plants without nematode inoculum. The plants in the greenhouse were maintained at $24 \pm 4^{\circ} \mathrm{C}$. and received similar horticultural treatments.

After sixty days of inoculation, plants were removed carefully from the plastic pots. Roots and surrounding soil in the pots were soaked in tap water for one hour to facilitate removing adhering soil and keep egg masses on the root surface. Roots were wrapped in tissue paper to prevent drying out during the steps of evaluation. Observations on plant growth parameters included: the fresh weight of shoot and roots and the leaves number. While $M$. incognita nematode parameters included: galling (galls No./root), reproduction (No. $\mathrm{IJ}_{2} /$ pot soil) and root-knot index.

The numbers of galls and egg masses were counted per root system under a dissecting microscope. Also, nematodes were extracted from soil using a combination of sieving and Baermann trays technique (Hooper, 1990). Besides, Root-knot index was assessed using (Taylor and Sasser, 1978) on a scale of $0=$ No galling; $1=1-2$ galls; $2=3-10$ galls; $3=$ 11 - 30 galls; $4=31-100$ galls and $5=$ more than 100 galls. Gall diameter was also measured at its greatest diameter.

\section{B. Curative Treatment:}

Effect of Oxamyl and Surfactant Combinations on Tomato Plants Infected with $M$. Incognita as A Curative Treatment:

One month after nematode inoculation, tomato plants infected with 1000 IJs of $M$. incognita were treated with $10 \mathrm{ml}$ of the combination of the recommended rates of each tested surfactant (Agrimax-3H, Silwet L-77, and Sylgard 309) and the recommended 
rate of oxamyl as a curative treatment to assess their effect on nematode reproduction under greenhouse conditions. Plants of the control treatment were left without any surfactant or oxamyl combinations. Plants were harvested one month later which means that experiment was-terminated 90 days after tomato transplanting. Data dealing with plant parameters (fresh weight of shoot and roots and leaves number) were determined. In each treatment, an aliquot soil sample was processed for nematode extraction. Nematodes were extracted using a combination of sieving and Baermann trays technique (Hooper, 1990). The number of juveniles was counted. As well as root galls and egg masses per one gram of root were counted. The percentage of nematode reduction (\%) was calculated according to the following equation:

$$
\text { Nematode reduction }(\%)=\frac{\text { No. of nematode in control }- \text { No. of nematode in treatment }}{\text { No. of nematode in control }} \times 100
$$

\section{Statistical and Data Analysis:}

The experiments were applied using the factorial experiment design in CRD. The data were transformed then analyzed using the analysis of variance followed by Duncan's New Multiple Range Test $(P=0.01)$ (COSTAT $V$. 6.45 statistical software, Cohort, Berkeley, California). The corrected juvenile mortality and egg hatching percentages were plotted against incubation days post-treatment and the median lethal/inhibition time in days ( $\mathrm{LT}_{50}$ values) was determined through probit analysis (Finney, 1971). Data statistical analysis was performed using the Biostat 2009 software [version5.8.4.3, 2010].

\section{RESULTS AND DISCUSSION}

The hatching percentages in egg masses of Meloidogyne incognita as affected by Agrimax-3H, Silwet L-77 and Sylgard 309 surfactants, oxamyl and their combinations are presented in Table (1). The data revealed that surfactants and oxamyl significantly $(P \leq 0$. $01)$ inhibited egg hatching of $M$. incognita. The inhibitory effect varied according to surfactant and oxamyl application rates at different exposure times. The long incubation period with the tested concentrations emphasized the crucial role of oxamyl concentration until the experimental endpoint.

After 14 days of the incubation period, the recommended dose of surfactants alone presented the highest significant hatching percentage $(49.32 \%)$ followed by oxamyl $1 / 2 \mathrm{R}+$ $1 / 2 \mathrm{R}$ surfactant (39.64\%). Whilst the treatment of $3 / 4 \mathrm{R}$ oxamyl+1/4 R surfactant occupied the third significant rank (27.21\%), then oxamyl alone at its recommended rate (10.86\%). Thus, oxamyl alone caused the least significant hatching percentages $(P \leq 0.01)$ after 14 days of incubation period and confirmed its ovicidal effectiveness on $M$. incognita egg masses. 
Table 1 Percentage of egg hatching (emerged juveniles) from egg masses of Meloidogyne incognita treated with different levels of oxamyl mixed with three surfactants with the complementary fraction of the recommended rate.

\begin{tabular}{|c|c|c|c|c|c|c|c|}
\hline \multirow{2}{*}{$\begin{array}{c}\text { Incubation } \\
\text { period } \\
\text { (days) }\end{array}$} & \multirow[b]{2}{*}{ Surfactant } & \multicolumn{4}{|c|}{ Oxamyl /surfactant application rate ${ }^{+}$} & \multirow[b]{2}{*}{ Mean } & \multirow[b]{2}{*}{ Interaction } \\
\hline & & $\mathbf{R S}^{++}$ & $\begin{array}{c}1 / 2 \text { RO }+1 / 2 \\
\text { RS }\end{array}$ & $\begin{array}{c}3 / 4 \text { RO }+1 / 4 \\
\text { RS }\end{array}$ & $\mathbf{R O}^{+++}$ & & \\
\hline \multirow[t]{4}{*}{$($ angs) } & Agrimax-3H & 37.71 & 20.79 & 17.71 & 10.04 & $\begin{array}{c}21.56^{\mathrm{c}} \\
(\mathbf{7 8 . 4 4 )}\end{array}$ & \multirow{4}{*}{$* *$} \\
\hline & Silwet L-77 & 58.94 & 44.23 & 27.93 & 10.04 & $\begin{array}{l}35.29^{\mathrm{b}} \\
\mathbf{( 6 4 . 7 1 )}\end{array}$ & \\
\hline & Sylgard 309 & 66.61 & 49.60 & 33.83 & 10.04 & $\begin{array}{c}40.02^{\mathrm{a}} \\
(\mathbf{5 9 . 9 8})\end{array}$ & \\
\hline & Mean & $\begin{array}{r}54.42^{\mathrm{a}} \\
\mathbf{( 4 5 . 5 8 )}\end{array}$ & $\begin{array}{l}38.21^{\mathrm{b}} \\
(61.79)\end{array}$ & $\begin{array}{l}26.49^{\mathrm{c}} \\
(\mathbf{7 3 . 5 1 )}\end{array}$ & $\begin{array}{l}10.04^{\mathrm{d}} \\
\mathbf{( 8 9 . 9 6 )}\end{array}$ & & \\
\hline \multirow{4}{*}{4} & Agrimax-3H & 50.87 & 32.45 & 17.05 & 10.17 & $\begin{array}{c}27.64^{\mathrm{c}} \\
(\mathbf{7 2 . 3 6})\end{array}$ & \multirow{4}{*}{$* *$} \\
\hline & Silwet L-77 & 58.36 & 53.89 & 22.25 & 10.17 & $\begin{array}{l}36.17^{\mathrm{b}} \\
(\mathbf{6 3 . 8 3})\end{array}$ & \\
\hline & Sylgard 309 & 69.87 & 51.28 & 22.28 & 10.17 & $\begin{array}{c}38.40^{\mathrm{a}} \\
\mathbf{( 6 1 . 6 0 )}\end{array}$ & \\
\hline & Mean & $\begin{array}{c}59.70^{\mathrm{a}} \\
\mathbf{( 4 0 . 3 0 )}\end{array}$ & $\begin{array}{l}45.87^{b} \\
(\mathbf{5 4 . 1 3 )}\end{array}$ & $\begin{array}{l}20.53^{\mathrm{c}} \\
(\mathbf{7 9 . 4 7 )}\end{array}$ & $\begin{array}{l}10.17^{\mathrm{d}} \\
\mathbf{( 8 9 . 8 3 )}\end{array}$ & & \\
\hline \multirow{4}{*}{7} & Agrimax-3H & 45.48 & 35.03 & 13.64 & 9.25 & $\begin{array}{l}25.85^{\mathrm{b}} \\
\mathbf{( 7 4 . 1 5 )}\end{array}$ & \multirow{4}{*}{$* *$} \\
\hline & Silwet L-77 & 50.03 & 45.96 & 22.71 & 9.25 & $\begin{array}{l}31.99^{\mathrm{a}} \\
(\mathbf{6 8 . 0 1 )}\end{array}$ & \\
\hline & Sylgard 309 & 51.50 & 44.67 & 21.64 & 9.25 & $\begin{array}{c}31.77^{\mathrm{a}} \\
(\mathbf{6 8 . 2 3})\end{array}$ & \\
\hline & Mean & $\begin{array}{l}49.00^{\mathrm{a}} \\
\mathbf{( 5 1 . 0 0 )}\end{array}$ & $\begin{array}{l}41.89^{b} \\
\mathbf{( 5 8 . 1 1 )}\end{array}$ & $\begin{array}{c}19.33^{\mathrm{c}} \\
\mathbf{( 8 0 . 6 7 )}\end{array}$ & $\begin{array}{c}9.25^{\mathrm{d}} \\
(\mathbf{9 0 . 7 5 )}\end{array}$ & & \\
\hline \multirow{4}{*}{10} & Agrimax-3H & 44.81 & 38.74 & 18.82 & 10.81 & $\begin{array}{l}28.30^{\mathrm{b}} \\
(\mathbf{7 1 . 7}) \\
\end{array}$ & \multirow{4}{*}{$* *$} \\
\hline & Silwet L-77 & 49.71 & 46.26 & 29.43 & 10.81 & $\begin{array}{r}34.05^{\mathrm{a}} \\
\mathbf{( 6 5 . 9 5 )}\end{array}$ & \\
\hline & Sylgard 309 & 56.26 & 46.44 & 28.43 & 10.81 & $\begin{array}{l}35.49^{\mathrm{a}} \\
(\mathbf{6 4 . 5 1 )}\end{array}$ & \\
\hline & Mean & $\begin{array}{l}50.26^{\mathrm{a}} \\
(49.74)\end{array}$ & $\begin{array}{l}43.81^{\mathrm{b}} \\
\mathbf{( 5 6 . 1 9 )}\end{array}$ & $\begin{array}{l}25.56^{\mathrm{c}} \\
(\mathbf{7 4 . 4 4 )}\end{array}$ & $\begin{array}{l}10.81^{\mathrm{d}} \\
\mathbf{( 8 9 . 1 9 )}\end{array}$ & & \\
\hline \multirow{4}{*}{14} & Agrimax-3H & 44.34 & 37.25 & 22.88 & 10.86 & $\begin{array}{l}28.83^{b} \\
(71.17)\end{array}$ & \multirow{4}{*}{$* *$} \\
\hline & Silwet L-77 & 51.66 & 37.91 & 25.35 & 10.86 & $\begin{array}{l}31.45^{\mathrm{b}} \\
\mathbf{( 6 8 . 5 5 )}\end{array}$ & \\
\hline & Sylgard 309 & 51.96 & 43.76 & 33.40 & 10.86 & $\begin{array}{l}35.00^{\mathrm{a}} \\
(\mathbf{6 5 . 0 0 )}\end{array}$ & \\
\hline & Mean & $\begin{array}{l}49.32^{\mathrm{a}} \\
\mathbf{5 0 . 6 8 )}\end{array}$ & $\begin{array}{l}39.64^{b} \\
(\mathbf{6 0 . 3 6 )}\end{array}$ & $\begin{array}{l}27.21^{\mathrm{c}} \\
(\mathbf{7 2 . 7 9 )}\end{array}$ & $\begin{array}{l}10.86^{\mathrm{d}} \\
\mathbf{( 8 9 . 1 4 )}\end{array}$ & & \\
\hline
\end{tabular}

-Numbers between parentheses refer to the reduction percentages resulted from treatment; the same letter (s) in each row or column means indicate no significant difference $(P \leq 0.01)$ between factor treatments according to Duncan's multiple range test.

+ The recommended rate of oxamyl : $0.2 \mathrm{ml} /$ plant $=48 \mathrm{mg}$ a.i. $/$ plant.

The recommended rates of surfactants: $15 \mathrm{ml} / 100 \mathrm{~L}, 5 \mathrm{ml} / 100 \mathrm{~L}$, and $250 \mathrm{ml} / 100 \mathrm{~L}$, respectively for Agrimax-3H $\mathrm{H}^{\circledR}$, Silwet $\mathrm{L}-77^{\circledR}$ and Sylgard $309^{\circledR}$.

++ RS: recommended rate of surfactant.

+++ RO: recommended rate of oxamyl.

The tested surfactant alone caused approximately 50\% hatching reduction. On the other hand, the three surfactants showed another fluctuated trend with the long incubation period such as Sylgard 309 which showed the highest significant hatching percentage among the tested ones (51.96\%) followed by Silwet L-77 (51.66\%). Finally, the highest potential ovicidal effect was obtained from Agrimax-3H (recorded the lowest hatching percentage 
comparing with other surfactants). This data trend continued until the $4^{\text {th }}$ day. However, on the $7^{\text {th }}$ day of treatment, Agrimax-3H has a significant difference (Fig.1, left column) with other tested surfactants and an insignificant difference $(P \leq 0.01)$ was observed between Silwet L-77 and Sylgard 309.

Agrimax 3 is a proprietary, multipurpose adjuvant composition. It is optimized microemulsions containing alkyl pyrrolidones, anionic surfactants and water-insoluble copolymers derived from vinyl pyrrolidones (Narayanan and Ianniello, 1996; Narayanan and Tallon, 1997). Adjuvants were used in pesticide formulations microemulsified as homogeneous, thermodynamically stable systems dilutable at all concentrations without separation (Parker, 1993). Agrimax systems are designed to provide increased spreading, penetration and rain fastness (Narayanan and Tallon, 1997) with enhanced biological activity with several herbicides when used as tank mix additives (Parker, 1993). The role of adjuvant in changing the physical characteristics of water is responsible for adjuvant toxicity (Imai et al., 1995). All these adjuvants are available in tank mix additive during the application of pesticide formulations.

Oxamyl alone at the recommended rate maintained the main effect on egg mass hatching by a $90 \%$ inhibition rate throughout the trial period. Oxamyl is a carbamate compound (Ntalli and Caboni, 2012) with contact and systemic insecticide, acaricide and nematicide absorbed by the foliage and roots, with translocation (Peterson et al., 1978). Oxamyl is an inhibitor of neurotransmission in nematodes through inhibition of acetylcholinesterase in synapses in the nervous system (Wright et al., 1980). This test nematicide may cause mortality directly or inhibition of development in such essentially sedentary juveniles as those of $M$. incognita (Wright and Womack, 1981).

Generally, the comparison tests confirm that the combination of oxamyl and Agrimax-3H showed significantly $(P \leq 0.01)$ more effectiveness against egg masses hatching. On the other hand, as exposure time increased from 2 to 14 days after treatments, the ovicidal effect of the tested materials was increased at all the tested rates.

Data in Table (2) show the juveniles hatched percentages from free eggs of Meloidogyne incognita treated with oxamyl + surfactants at different levels of application rates expressed as the complementary fraction of recommended rates. The data trend in Table (2) was very similar with Table (1) with a little dissimilarity in the significant difference of surfactant means which continued until 10 days after treatment, where, Sylgard 309 occupied the highest significant hatching percentage $(47.49 \%)$ followed by Silwet L-77 $(50.35 \%)$ in the second significant rank and finally, Agrimax-3H (63.67\%) recorded the lowest significant hatching percentage to preserve the front as the most ovicidal surfactant. This trend changed after 14 days of incubation to show the insignificant difference $(P \leq 0.01)$ between Sylgard 309 and Silwet L-77, while, Agrimax-3H gained a significant difference (Fig.1, right column).

Data in the Tables $(1,2)$ showed a highly significant interaction between oxamyl concentration and surfactants levels supporting the assumption that the role of adding surfactants is enhancing the ovicidal effect of oxamyl on egg masses and free eggs of $M$. incognita depending on the combined ratio and ascertained the oxamyl levels as the dependent variable in combination potency, as shown in Fig. (1).

Root-knot nematode females lay eggs into a gelatinous matrix (Maggenti and Allen, 1960) which serves as a defensive barrier to water loss by maintaining a high moisture level around the eggs (Mahmud and Wesemael, 2014; Wallace, 1968). As the gelatinous matrix ages, it becomes tanned, turning from a sticky, colorless jelly to an orange-brown substance that appears layered (Bird, 1958). Meloidogyne incognita eggs developed to the first stage juvenile on the fourth day while the second-stage juvenile appeared on the seventh day in the water (Jung et al., 2002). The role of tested adjuvants may result from the solubility 
changing the physical properties of water which facilitate the oxamyl penetration to the gelatinous matrix surrounded the egg masses. It requires a long period depending on the thickness of the gelatinous layer so the effect on the hatching percentage of tested adjuvant alone was lower in egg masses while hatching of free eggs was higher than egg masses. Egg hatching induced changes in eggshell permeability, hatching may involve physical and/or enzymatic processes in plant-parasitic nematodes (Sudirman, 1995).

Table 2 Percentage of egg hatching (emerged juveniles) from free eggs of Meloidogyne incognita treated with different levels of oxamyl mixture with three surfactants with the complementary fraction of the recommended rate.

\begin{tabular}{|c|c|c|c|c|c|c|c|}
\hline \multirow{2}{*}{$\begin{array}{c}\text { Incubation } \\
\text { period } \\
\text { (days) }\end{array}$} & \multirow[b]{2}{*}{ Surfactant } & \multicolumn{4}{|c|}{ Oxamyl /surfactant application rate+ } & \multirow[b]{2}{*}{ Mean } & \multirow[b]{2}{*}{ Interaction } \\
\hline & & $\mathbf{R S}^{++}$ & $\begin{array}{c}1 / 2 \text { RO + } \\
1 / 2 \text { RS }\end{array}$ & $\begin{array}{c}3 / 4 \text { RO + 1/4 } \\
\text { RS }\end{array}$ & $\mathbf{R O}^{+++}$ & & \\
\hline \multirow[t]{4}{*}{ (2) } & Agrimax-3H & 27.19 & 44.74 & 40.35 & 3.95 & $\begin{array}{c}29.06^{\mathrm{c}} \\
\mathbf{( 7 0 . 9 4 )}\end{array}$ & \multirow{4}{*}{$* *$} \\
\hline & Silwet L-77 & 81.58 & 50.00 & 35.96 & 3.95 & $\begin{array}{r}42.87^{b} \\
\mathbf{( 5 7 . 1 3 )}\end{array}$ & \\
\hline & Sylgard 309 & 91.23 & 64.91 & 42.98 & 3.95 & $\begin{array}{c}50.77^{a} \\
(\mathbf{4 9 . 2 3 )}\end{array}$ & \\
\hline & Mean & $\begin{array}{c}66.67^{\mathrm{a}} \\
\mathbf{( 3 3 . 3 3 )}\end{array}$ & $\begin{array}{c}53.22^{\mathrm{b}} \\
\mathbf{( 4 6 . 7 8 )}\end{array}$ & $\begin{array}{l}39.76^{\mathrm{c}} \\
(\mathbf{6 0 . 2 4 )}\end{array}$ & $\begin{array}{c}3.95^{\mathrm{d}} \\
(\mathbf{9 6 . 0 5 )}\end{array}$ & & \\
\hline \multirow{4}{*}{4} & Agrimax-3H & 48.25 & 75.73 & 38.30 & 8.48 & $\begin{array}{c}42.69^{\mathrm{c}} \\
\mathbf{( 5 7 . 3 1 )}\end{array}$ & \multirow{4}{*}{$* *$} \\
\hline & Silwet L-77 & 87.72 & 50.58 & 61.11 & 8.48 & $\begin{array}{c}51.97^{b} \\
\mathbf{( 4 8 . 0 3 )}\end{array}$ & \\
\hline & Sylgard 309 & 93.57 & 77.49 & 71.35 & 8.48 & $\begin{array}{c}62.72^{a} \\
(\mathbf{3 7 . 2 8})\end{array}$ & \\
\hline & Mean & $\begin{array}{l}76.51^{\mathrm{a}} \\
(\mathbf{2 3 . 4 9 )}\end{array}$ & $\begin{array}{l}67.93^{\mathrm{b}} \\
\mathbf{( 3 2 . 0 7 )}\end{array}$ & $\begin{array}{c}56.92^{\mathrm{c}} \\
(43.08)\end{array}$ & $\begin{array}{c}8.48^{\mathrm{d}} \\
\mathbf{( 9 1 . 5 2 )}\end{array}$ & & \\
\hline \multirow{4}{*}{7} & Agrimax-3H & 43.12 & 53.57 & 29.50 & 11.77 & $\begin{array}{l}34.49^{\mathrm{c}} \\
\mathbf{( 6 5 . 5 1 )}\end{array}$ & \multirow{4}{*}{$* *$} \\
\hline & Silwet L-77 & 75.53 & 41.93 & 56.61 & 11.77 & $\begin{array}{r}46.46^{b} \\
\mathbf{( 5 3 . 5 4 )} \\
\end{array}$ & \\
\hline & Sylgard 309 & 84.26 & 65.48 & 48.54 & 11.77 & $\begin{array}{c}52.51^{\mathrm{a}} \\
\mathbf{( 4 7 . 4 9 )}\end{array}$ & \\
\hline & Mean & $\begin{array}{c}67.64^{\mathrm{a}} \\
\mathbf{( 3 2 . 3 6 )} \\
\end{array}$ & $\begin{array}{c}53.66^{\mathrm{b}} \\
(\mathbf{4 6 . 3 4 )}\end{array}$ & $\begin{array}{l}44.88^{c} \\
\mathbf{( 5 5 . 1 2 )} \\
\end{array}$ & $\begin{array}{r}11.77^{\mathrm{d}} \\
\mathbf{( 8 8 . 2 3 )} \\
\end{array}$ & & \\
\hline \multirow{4}{*}{10} & Agrimax-3H & 45.67 & 54.92 & 33.84 & 10.89 & $\begin{array}{r}36.33^{\mathrm{c}} \\
(\mathbf{6 3 . 6 7 )}\end{array}$ & \multirow{4}{*}{$* *$} \\
\hline & Silwet L-77 & 80.80 & 43.56 & 63.35 & 10.89 & $\begin{array}{r}49.65^{b} \\
\mathbf{( 5 0 . 3 5 )}\end{array}$ & \\
\hline & Sylgard 309 & 87.94 & 69.44 & 49.65 & 10.89 & $\begin{array}{r}54.48^{\mathrm{a}} \\
\mathbf{( 4 5 . 5 2 )}\end{array}$ & \\
\hline & Mean & $\begin{array}{l}71.47^{\mathrm{a}} \\
\mathbf{( 2 8 . 5 3 )}\end{array}$ & $\begin{array}{l}55.97^{\mathrm{b}} \\
\mathbf{( 4 4 . 0 3 )}\end{array}$ & $\begin{array}{l}48.95^{\mathrm{c}} \\
\mathbf{( 5 1 . 0 5 )}\end{array}$ & $\begin{array}{r}10.89^{d} \\
\mathbf{( 8 9 . 1 1 )}\end{array}$ & & \\
\hline \multirow{4}{*}{14} & Agrimax-3H & 66.36 & 63.10 & 37.92 & 10.81 & $\begin{array}{r}44.55^{b} \\
\mathbf{( 5 5 . 4 5 )}\end{array}$ & \multirow{4}{*}{$* *$} \\
\hline & Silwet L-77 & 82.98 & 50.97 & 67.48 & 10.81 & $\begin{array}{r}53.06^{\mathrm{a}} \\
\mathbf{( 4 6 . 9 4 )}\end{array}$ & \\
\hline & Sylgard 309 & 89.81 & 53.41 & 72.99 & 10.81 & $\begin{array}{r}56.76^{\mathrm{a}} \\
\mathbf{( 4 3 . 2 4 )}\end{array}$ & \\
\hline & Mean & $\begin{array}{l}79.72^{\mathrm{a}} \\
(\mathbf{2 0 . 2 8})\end{array}$ & $\begin{array}{c}55.83^{\mathrm{b}} \\
\mathbf{( 4 4 . 1 7 )}\end{array}$ & $\begin{array}{l}59.46^{\mathrm{b}} \\
\mathbf{( 4 0 . 5 4 )}\end{array}$ & $\begin{array}{c}10.81^{\mathrm{c}} \\
(\mathbf{8 9 . 1 9 )}\end{array}$ & & \\
\hline
\end{tabular}

-Numbers between parentheses refer to the reduction percentages resulted from treatment; The same letter (s) in each row or column means indicate no significant difference $(P \leq 0.01)$ between factor treatments according to Duncan's multiple range test.

+ The recommended rate of oxamyl : $0.2 \mathrm{ml} /$ plant $=48 \mathrm{mg}$ a.i./ plant.

The recommended rates of surfactants: $15 \mathrm{ml} / 100 \mathrm{~L}, 5 \mathrm{ml} / 100 \mathrm{~L}$, and $250 \mathrm{ml} / 100 \mathrm{~L}$, respectively for Agrimax-3 $\mathrm{H}^{\circledR}$, Silwet L-7 ${ }^{\circledR}$ and Sylgard $309^{\circledR}$.

$++\mathrm{RS}$ : recommended rate of surfactant.

+++ RO: recommended rate of oxamyl. 

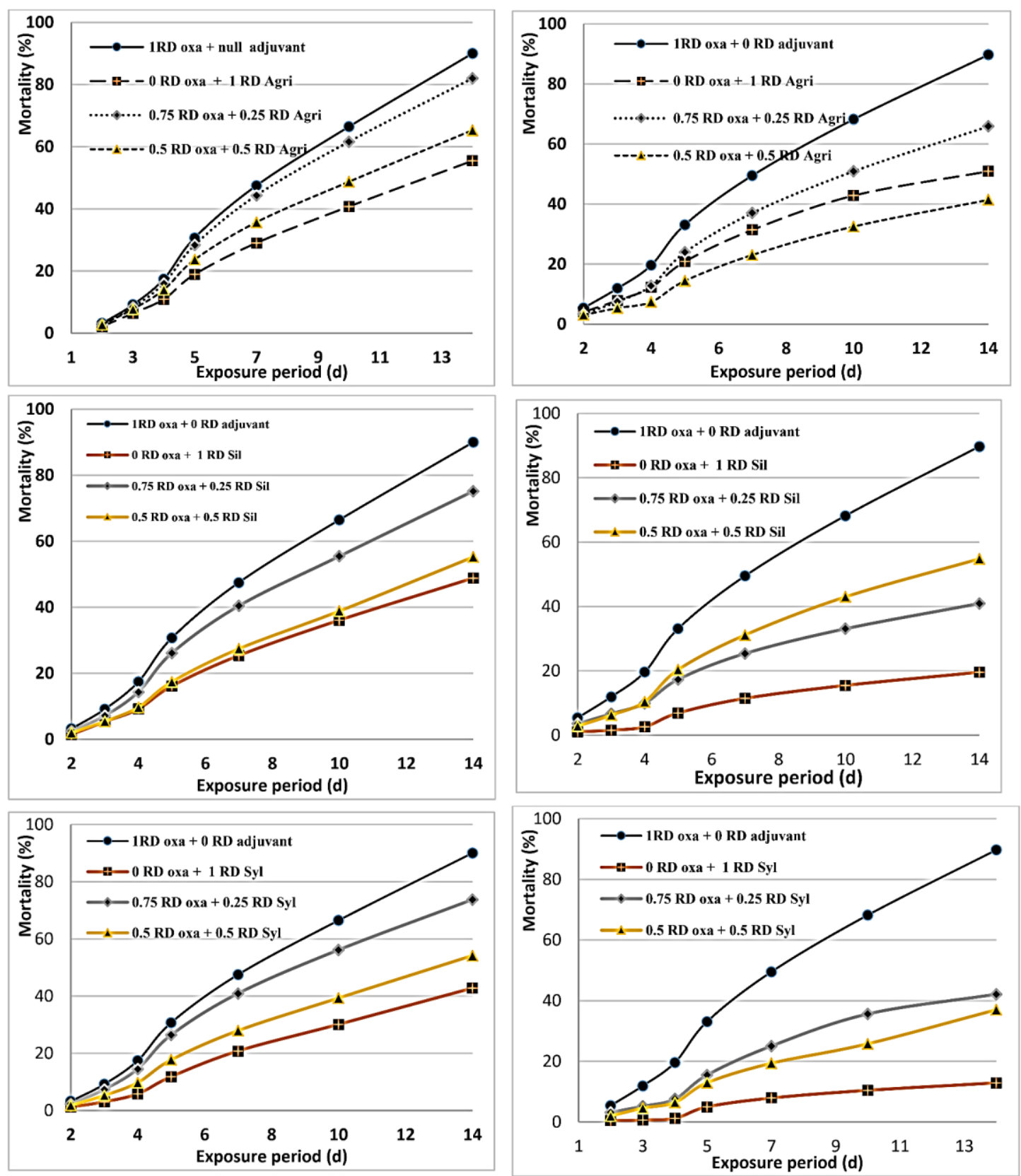

Fig. 1 Accumulative eggs or egg masses of Meloidogyne incognita hatching percentage reduction of different combinations of oxamyl and surfactant (Agrimax-3H, Silwet L-77 and Sylgard 309).

Egg masses (left column) and Free eggs (right column) of Meloidogyne incognita.

The second explanation is synchronization eggshell permeability disruption with the formation of the nervous system of the juvenile stage which complete on the fourth day (Jung et al., 2002) as shown in Figs (1 and 2). The high rise in the potency of different treatments was revealed in the $5^{\text {th }}$ days of incubation where, oxamyl is ready to enter the egg with enough amount with the presence of oxamyl target (nervous system, the chemical transmitter "AChE") leading to death juveniles before egg hatching. Eggs hatching of M. incognita decreased with increasing concentration of nematicides (Haq et al., 1983). These probable mechanisms elucidate Agrimax-3H surpass other surfactants because Agrimax is a multipurpose adjuvant containing alkyl pyrrolidones, anionic surfactants and waterinsoluble copolymers derived from vinyl pyrrolidones (Narayanan and Ianniello, 1996; 
Narayanan and Tallon, 1997) to provide increased spreading, penetration and rain fastness. While Silwet L-77 and Sylgard 309 are wetting, superior spreading (Zabkiewwicz and Stevens, 1992) due to the influence on the solution surface tension (Castro et al., 2018).

Table (3) display dead juveniles ( $\left.\mathrm{IJ}_{2}\right)$ as percentages of $M$. incognita treated with the combinations of oxamyl + surfactant with the complementary fraction of recommended rates. Based on the level of oxamyl, $1 \mathrm{R}$ always showed the highest significant reduction percentage for $\mathrm{IJ}_{2}(95.10 \%)$ followed by $3 / 4 \mathrm{R}$ oxamyl $(15.30 \%)$. Finally, the treatment-free oxamyl (surfactant alone) showed the lowest significant reduction percentage $(0.20 \%)$. This trend of oxamyl levels extended to the experimental endpoint. While surfactant levels showed an insignificant difference $(P \leq 0.01)$ until the $6^{\text {th }}$ day after treatment with no interaction with oxamyl levels. On the $7^{\text {th }}$ day after incubation, Agrimax-3H recorded the highest significant reduction (29.28\%), followed by Sylgard 309 (27.75\%) recorded the lowest significant reduction percentage, while, Silwet L-77 mediated both surfactant (28.35\%) with no significant difference. After 10 days of incubation, a significant difference was exhibited between all surfactants. The high significant interaction between the oxamyl and surfactant levels started from the $7^{\text {th }}$ day's treatment. The reduction percentages of $\mathrm{IJ}_{2}$ of M. incognita treated with different oxamyl + surfactant combination is shown in Fig. (1).
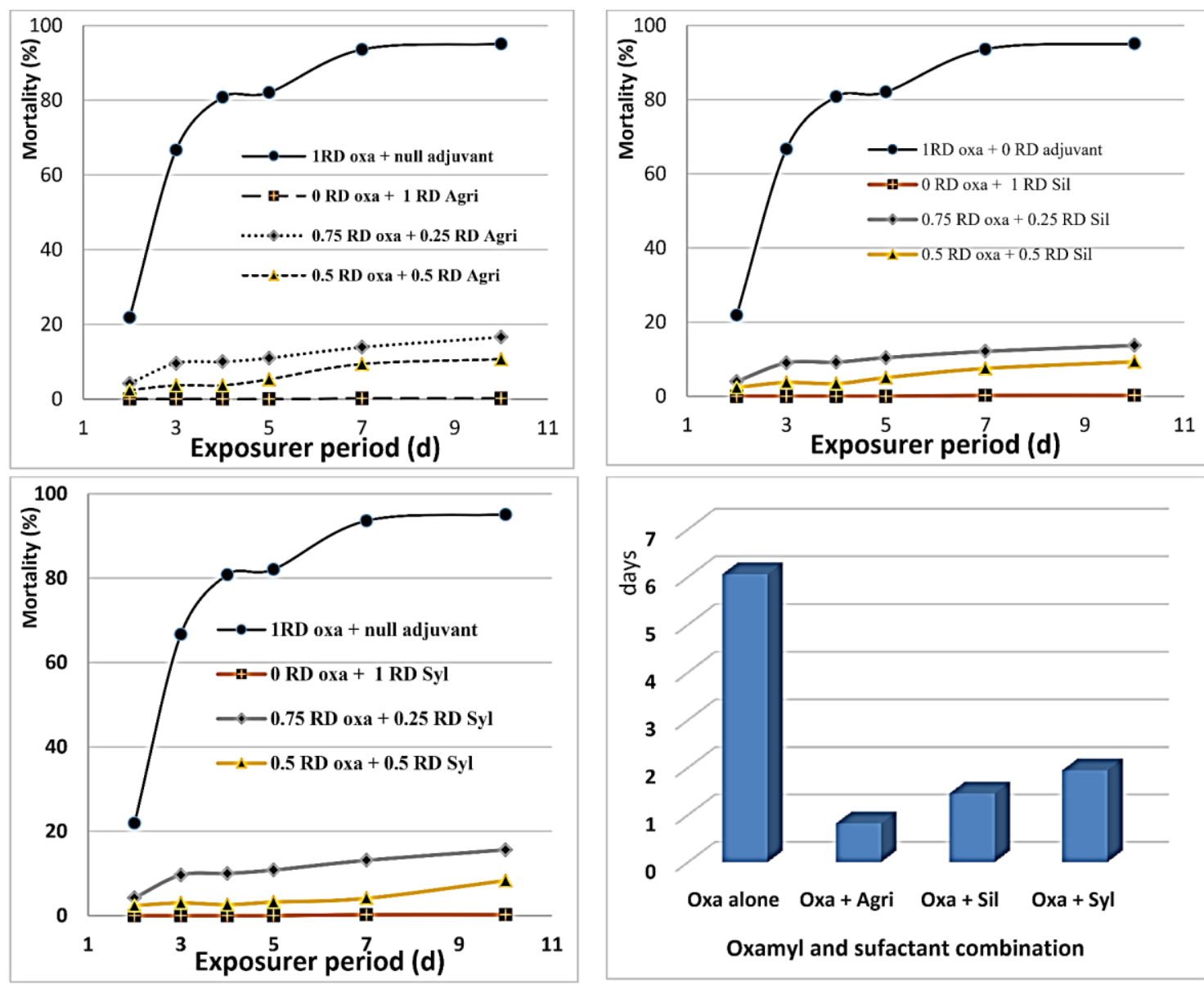

Fig. 2. Accumulative mortality of $\mathrm{IJ}_{2}$ of Meloidogyne incognita exposed to different combinations of oxamyl and surfactant (Agrimax-3H, Silwet L-77 and Sylgard 309); The median lethal time $\left(\mathrm{LT}_{50}\right)$ for oxamyl "Vydate ${ }^{\circledR} 24 \%$ SL" mixed recommended rated with different surfactant. 
Table 3. Percentages of dead juveniles of Meloidogyne incognita treated with different levels of oxamyl mixture with three surfactants with the complementary fraction of the recommended rate.

\begin{tabular}{|c|c|c|c|c|c|c|c|}
\hline \multirow{2}{*}{$\begin{array}{c}\text { Incubation } \\
\text { period } \\
\text { (days) }\end{array}$} & \multirow[b]{2}{*}{ Surfactant } & \multicolumn{4}{|c|}{ Oxamyl /surfactant application rate+ } & \multirow[b]{2}{*}{ Mean } & \multirow[b]{2}{*}{ Interaction } \\
\hline & & RS++ & 1/2RO+1/2RS & 3/4RO+1/4RS & RO+++ & & \\
\hline \multirow{4}{*}{2} & Agrimax-3H & 0.00 & 2.40 & 4.20 & 21.90 & $7.13^{\mathrm{a}}$ & \multirow{4}{*}{ Ns } \\
\hline & Silwet L-77 & 0.00 & 2.40 & 4.00 & 21.90 & $7.08^{\mathrm{a}}$ & \\
\hline & Sylgard 309 & 0.00 & 2.40 & 4.20 & 21.90 & $7.13^{\mathrm{a}}$ & \\
\hline & Mean & $0.00^{\mathrm{d}}$ & $2.40^{\mathrm{c}}$ & $4.13^{b}$ & $21.90^{\mathrm{a}}$ & & \\
\hline \multirow{4}{*}{4} & Agrimax-3H & 0.00 & 3.70 & 10.00 & 80.80 & $23.63^{\mathrm{a}}$ & \multirow{4}{*}{ Ns } \\
\hline & Silwet L-77 & 0.00 & 3.40 & 9.20 & 80.80 & $23.35^{\mathrm{a}}$ & \\
\hline & Sylgard 309 & 0.00 & 2.60 & 10.00 & 80.80 & $23.35^{\mathrm{a}}$ & \\
\hline & Mean & $0.00^{\mathrm{e}}$ & $3.23^{c}$ & $9.73^{b}$ & $80.80^{\mathrm{a}}$ & & \\
\hline \multirow{4}{*}{6} & Agrimax-3H & 0.00 & 5.30 & 11.00 & 82.10 & $24.60^{\mathrm{a}}$ & \multirow{4}{*}{ Ns } \\
\hline & Silwet L-77 & 0.00 & 5.00 & 10.40 & 82.10 & $24.38^{\mathrm{a}}$ & \\
\hline & Sylgard 309 & 0.00 & 3.20 & 10.80 & 82.10 & $24.03^{\mathrm{a}}$ & \\
\hline & Mean & $0.00^{d}$ & $4.50^{c}$ & $10.73^{b}$ & $82.10^{\mathrm{a}}$ & & \\
\hline \multirow{4}{*}{7} & Agrimax-3H & 0.20 & 9.40 & 13.90 & 93.60 & $29.28^{\mathrm{a}}$ & \multirow{4}{*}{$* *$} \\
\hline & Silwet L-77 & 0.20 & 7.50 & 12.10 & 93.60 & $28.35^{\mathrm{ab}}$ & \\
\hline & Sylgard 309 & 0.20 & 4.10 & 13.10 & 93.60 & $27.75^{b}$ & \\
\hline & Mean & $0.20^{\mathrm{d}}$ & $7.00^{c}$ & $13.03^{b}$ & $93.60^{\mathrm{a}}$ & & \\
\hline \multirow{4}{*}{10} & Agrimax-3H & 0.20 & 10.70 & 16.60 & 95.10 & $30.65^{\mathrm{a}}$ & \multirow{4}{*}{$* *$} \\
\hline & Silwet L-77 & 0.20 & 9.30 & 13.70 & 95.10 & $29.58^{\mathrm{b}}$ & \\
\hline & Sylgard 309 & 0.20 & 8.30 & 15.60 & 95.10 & $29.80^{\mathrm{b}}$ & \\
\hline & Mean & $0.20^{\mathrm{d}}$ & $9.43^{c}$ & $15.30^{\mathrm{b}}$ & $95.10^{\mathrm{a}}$ & & \\
\hline
\end{tabular}

-The same letter $(\mathrm{s})$ in each row or column means indicate no significant difference $(P \leq 0.01)$ between factor treatments according to Duncan's multiple range test.

+ The recommended rates of surfactants: $15 \mathrm{ml} / 100 \mathrm{~L}, 5 \mathrm{ml} / 100 \mathrm{~L}$, and $250 \mathrm{ml} / 100 \mathrm{~L}$, respectively for Agrimax-3 $\mathrm{H}^{\circledR}$, Silwet L-77 ${ }^{\circledR}$ and Sylgard $309^{\circledR}$.

The recommended rate of oxamyl : $0.2 \mathrm{ml} /$ plant $=48 \mathrm{mg}$ a.i./ plant . $++\mathrm{RS}$ : recommended rate of surfactant.

The infective second-stage $\left(\mathrm{IJ}_{2}\right)$ is the first molt that emerged from the egg. The newly hatched juveniles have a short free-living stage in the soil, in the rhizosphere of the host plants. They may reinvade the host plants of their parent or migrate through the soil to find a new host root (Eisenback and Triantaphyllou, 1991). Meloidogyne incognita eggs developed to the first stage juvenile on the fourth day while the second-stage juvenile appeared on the seventh day in the water (Jung et al., 2002) this mean that the nervous system is a susceptible target to oxamyl toxicity that depends on toxicokinetic e.g. the amount uptake, absorbed, and translocated in organism reaching to the target sites "synapses" where the AChE is present. The latent period of oxamyl depends on these processes, so, in Fig. (2) $\mathrm{IJ}_{2}$ mortality showed an accelerated increase from the $2^{\text {nd }}$ day to the $4^{\text {th }}$ day followed by a limited increase in mortality percentage. The merit of the combination of oxamyl (Vydate ${ }^{\circledR}$ $24 \% \mathrm{SL}$ ) and surfactants at recommended rates of both (Fig.2, bottom-right), where, oxamyl formulation alone required 6.06 days for killing $50 \%\left(\mathrm{LT}_{50}\right)$ of exposed $\mathrm{IJ}_{2}$. While adding surfactants with recommended rate to oxamyl formulation speed up the latent period to record 1.45 days for Silwet L-77 LT 50 and 1.95 days with Sylgard 309. Moreover, Agrimax$3 \mathrm{H}$ shorted the $\mathrm{LT}_{50}$ of oxamyl to 0.82 days increasing the nematicidal effect of oxamyl.

The tested adjuvants may play a role in the toxicity process but not directly because until the $6^{\text {th }}$-day treatment there was no significance between the tested adjuvants and no interaction between adjuvant and oxamyl level. In contrast with the sequential days of treatment, a significant difference between the tested adjuvants appeared gradually and interaction with oxamyl level ascertain that adjuvants cause light, slow and accumulated 
toxicity and incomparable with egg/ egg masses treated with the mentioned combinations. El-Ashry et al. (2019) demonstrated that the tested adjuvants cause a good inhibition of egg hatching, while, limited mortality to $\mathrm{IJ}_{2}$ of Meloidogyne incognita resulted even with increasing the tested concentration to $2 \mathrm{R}$. The insusceptibility of $\mathrm{IJ}_{2}$ proves that $\mathrm{IJ} 2$ is less affected by adjuvant and changing resulted in water physical properties comparing with egg.

Table (4) show the plant growth parameters as well as nematode parameters as influenced by the addition of recommended doses of surfactants and different application rates of oxamyl in protective treatment. The highest significant reduction in root weight was recorded with Agrimax- $3 \mathrm{H}$ at $3 / 4 \mathrm{R}$ of oxamyl followed by Agrimax-3H mixed with $1 \mathrm{R}$ oxamyl, whereas, the highest leaves number was significantly noticed with $1 \mathrm{R}$ oxamyl free of surfactant addition. The fresh root weight is considered an indirect parameter for plant healthy because of the latent effect of nematode infection.

The parameters related to nematode infection e.g. number of egg masses recorded the lowest significant reduction with oxamyl without surfactant followed by $1 \mathrm{R}$ oxamyl $+1 \mathrm{R}$ Agrimax-3H. Also, the galls number showed the lowest significant value in the same treatment. Based on galls diameter, Agrimax-3H showed a vigor effect near to oxamyl alone inducing galls formation $4 \mathrm{~mm}$ diameter, but, oxamyl applied at $1 \mathrm{R}$ without surfactant was significantly superior in reducing galls formation $<4$ to $2 \mathrm{~mm}$ diameter (0.8). Oxamyl alone at $1 \mathrm{R}$ caused the lowest significant reduction in the population density of $\mathrm{IJ}_{2} / 100 \mathrm{~g}$ soil. Statistical analysis showed a highly significant between oxamyl and surfactant levels with all measured parameters except gall formation categories $\leq 2 \mathrm{~mm}$ and 2 to $4 \mathrm{~mm}$ diameter.

There is no doubt that every manufacturer of pesticides seeks to formulate the active ingredient to reach the formulation to the maximum possible efficiency taking into account all the nonoptimal conditions that the formulation faces starting from storage, mitigation, application, protection from phyto/microbial degradation and also the speed of runoff or leaching with water after irrigation. Based on the preventive treatment of the tested combination, it must be recognized that one treatment of the oxamyl nematicide is insufficient to prevent infection, especially that the evaluation of the disease was recorded after 60 days of treatment, therefore, it was necessary to repeat the application with oxamyl due to the dissipation of the pesticide. Oxamyl residues are not effective enough to protect plants from nematode infection. Also, the first preventive treatment of the nematicide is impossible to kill all infective stages of the nematode with only one treatment. So, the preventive evaluation was insufficient to judge the feasibility of the tested combinations, and it was necessary to use curative supplementary treatments between mixtures of oxamyl and adjuvants.

Data in Table (5) show the curative effect of recommended doses of oxamyl with surfactants on root-knot nematode, $M$. incognita infection and reproduction. The same trend was observed for tested parameters. All tested nematode parameters were reduced significantly $(P \leq 0.01)$ in treatments that received the recommended rate of oxamyl compared to treatments free of oxamyl application. While Silwet L-77 and Sylgard 309 recorded the lowest effectiveness against $M$. incognita and their mixture decreased oxamyl efficiency. On the other hand, significant variations were detected between Agrimax-3H and oxamyl alone and presented the vigor nematicidal effect of Agrimax-3H mixture with oxamyl at recommended dose or oxamyl alone with all tested parameters. 
Table 4 Tomato growth parameters, reproduction and root-gall formation of Meloidogyne incognita treated with the combination of Silwet L-77, Sylgard 309 and Agrimax$3 \mathrm{H}$ with oxamyl at different application rates.

\begin{tabular}{|c|c|c|c|c|c|c|c|}
\hline \multirow[b]{2}{*}{ Parameter } & \multirow{2}{*}{$\begin{array}{c}\text { Oxamyl }^{+} \\
\text {application } \\
\text { rate }\end{array}$} & \multicolumn{4}{|c|}{ Surfactants at the recommended rate ${ }^{++}$} & \multirow[b]{2}{*}{ Mean } & \multirow[b]{2}{*}{ Interaction } \\
\hline & & None & $\begin{array}{c}\text { Agrimax- } \\
3 \mathrm{H}\end{array}$ & $\begin{array}{c}\text { Silwet L- } \\
77\end{array}$ & $\begin{array}{c}\text { Sylgard } \\
309\end{array}$ & & \\
\hline \multirow{5}{*}{$\begin{array}{c}\text { Fresh } \\
\text { shoot } \\
\text { weight }\end{array}$} & 0.0 & 4.74 & 5.15 & 5.06 & 4.85 & $4.95^{c}$ & \multirow{5}{*}{$* *$} \\
\hline & $0.5 \mathrm{R}$ & 6.05 & 6.31 & 5.88 & 5.88 & 6.03 ${ }^{b}$ & \\
\hline & $0.75 \mathrm{R}$ & 6.71 & 7.57 & 4.86 & 6.58 & $6.43{ }^{\mathrm{a}}$ & \\
\hline & $1 \mathrm{R}$ & 6.77 & 6.88 & 5.55 & 5.73 & $6.24^{\mathrm{ab}}$ & \\
\hline & Mean & $6.07^{b}$ & $6.48^{a}$ & $5.34^{d}$ & $5.76^{c}$ & $(5.91)$ & \\
\hline \multirow{5}{*}{$\begin{array}{c}\text { Fresh root } \\
\text { weight }\end{array}$} & 0.0 & 5.91 & 8.23 & 7.56 & 6.50 & $7.05^{c}$ & \multirow{5}{*}{$* *$} \\
\hline & $0.5 \mathrm{R}$ & 5.34 & 8.96 & 7.18 & 6.88 & $7.09^{c}$ & \\
\hline & $0.75 \mathrm{R}$ & 6.36 & 10.79 & 6.11 & 8.02 & $7.82^{b}$ & \\
\hline & $1 \mathrm{R}$ & 10.09 & 11.78 & 7.04 & 7.73 & $9.16^{a}$ & \\
\hline & Mean & $6.92^{b}$ & $9.94^{a}$ & $6.97^{b}$ & $7.28^{a}$ & $(7.78)$ & \\
\hline \multirow{5}{*}{$\begin{array}{l}\text { Number } \\
\text { of leaves }\end{array}$} & 0.0 & 4.80 & 4.40 & 4.40 & 4.40 & $4.50^{c}$ & \multirow{5}{*}{$* *$} \\
\hline & $0.5 \mathrm{R}$ & 13.80 & 4.20 & 4.80 & 4.40 & $6.80^{b}$ & \\
\hline & $0.75 \mathrm{R}$ & 11.40 & 6.60 & 4.40 & 7.60 & $7.50^{\mathrm{ab}}$ & \\
\hline & $1 \mathrm{R}$ & 11.80 & 11.80 & 4.40 & 4.80 & $8.20^{\mathrm{a}}$ & \\
\hline & Mean & $10.45^{a}$ & $6.75^{b}$ & $4.50^{c}$ & $5.30^{\mathrm{c}}$ & $(6.75)$ & \\
\hline \multirow{5}{*}{$\begin{array}{l}\text { No. egg } \\
\text { masses }\end{array}$} & 0.0 & 71.20 & 58.20 & 65.80 & 65.80 & $65.25^{a}$ & \multirow{5}{*}{$* *$} \\
\hline & $0.5 \mathrm{R}$ & 15.40 & 42.60 & 45.20 & 47.40 & $37.65^{b}$ & \\
\hline & $0.75 \mathrm{R}$ & 12.20 & 11.20 & 34.00 & 25.40 & $20.70^{c}$ & \\
\hline & $1 \mathrm{R}$ & 3.60 & 3.80 & 15.00 & 11.60 & $8.50^{d}$ & \\
\hline & Mean & $25.60^{b}$ & $28.95^{b}$ & $40.00^{a}$ & $37.55^{a}$ & $(33.02)$ & \\
\hline \multirow{5}{*}{$\begin{array}{l}\text { No. of } \\
\text { galls }\end{array}$} & 0.0 & 30.60 & 26.20 & 34.20 & 34.20 & $31.30^{\mathrm{a}}$ & \multirow{5}{*}{$* *$} \\
\hline & $0.5 \mathrm{R}$ & 6.00 & 35.20 & 30.00 & 40.40 & $27.90^{b}$ & \\
\hline & $0.75 \mathrm{R}$ & 4.50 & 2.40 & 26.60 & 16.00 & $12.38^{c}$ & \\
\hline & $1 \mathrm{R}$ & 1.20 & 1.40 & 11.60 & 6.60 & $5.20^{d}$ & \\
\hline & Mean & $10.58^{c}$ & $16.30^{b}$ & $25.60^{a}$ & $24.30^{\mathrm{a}}$ & $(19.20)$ & \\
\hline \multirow{5}{*}{$\begin{array}{l}\text { No. gall } \\
>4 \mathrm{~mm}\end{array}$} & 0.0 & 2.20 & 2.00 & 1.80 & 1.80 & $1.95^{\mathrm{a}}$ & \multirow{5}{*}{ ns } \\
\hline & $0.5 \mathrm{R}$ & 1.20 & 0.60 & 1.00 & 1.00 & $0.95^{b}$ & \\
\hline & $0.75 \mathrm{R}$ & 0.80 & 1.40 & 1.40 & 0.80 & $1.10^{b}$ & \\
\hline & $1 \mathrm{R}$ & 0.00 & 0.00 & 0.40 & 0.60 & $0.25^{\mathrm{c}}$ & \\
\hline & Mean & $1.05^{a}$ & $1.00^{a}$ & $1.15^{\mathrm{a}}$ & $1.05^{a}$ & $(1.06)$ & \\
\hline \multirow{5}{*}{$\begin{array}{c}\text { No. galls } \\
<4 \text { to } 2 \\
\text { mm }\end{array}$} & 0.0 & 13.00 & 12.00 & 13.40 & 13.40 & $12.95^{b}$ & \multirow{5}{*}{$* *$} \\
\hline & $0.5 \mathrm{R}$ & 6.00 & 22.80 & 18.40 & 25.20 & $18.10^{\mathrm{a}}$ & \\
\hline & $0.75 \mathrm{R}$ & 2.20 & 1.40 & 10.40 & 9.00 & $5.75^{b}$ & \\
\hline & $1 \mathrm{R}$ & 0.80 & 1.20 & 6.20 & 4.20 & $3.10^{d}$ & \\
\hline & Mean & $5.50^{c}$ & $9.35^{b}$ & $12.10^{\mathrm{a}}$ & $12.95^{\mathrm{a}}$ & $(9.98)$ & \\
\hline \multirow{5}{*}{$\begin{array}{l}\text { No. galls } \\
\text { less } 2 \mathrm{~mm}\end{array}$} & 0.0 & 15.40 & 13.00 & 19.60 & 19.60 & $16.90^{\mathrm{a}}$ & \multirow{5}{*}{ ns } \\
\hline & $0.5 \mathrm{R}$ & 5.00 & 11.80 & 10.60 & 14.20 & $10.40^{b}$ & \\
\hline & $0.75 \mathrm{R}$ & 3.20 & 1.00 & 11.40 & 6.20 & $5.45^{\mathrm{c}}$ & \\
\hline & $1 \mathrm{R}$ & 0.40 & 1.00 & 5.00 & 2.00 & $2.10^{c}$ & \\
\hline & Mean & $6.00^{c}$ & $6.70^{b c}$ & $11.65^{a}$ & $10.50^{\mathrm{ab}}$ & (8.71) & \\
\hline \multirow{5}{*}{$\begin{array}{l}\text { No. IJs } \\
\text { /100 g soil }\end{array}$} & 0.0 & 56.00 & 49.80 & 53.80 & 53.80 & $53.35^{a}$ & \\
\hline & $0.5 \mathrm{R}$ & 9.00 & 47.00 & 52.00 & 49.40 & $39.35^{b}$ & \\
\hline & $0.75 \mathrm{R}$ & 5.80 & 9.40 & 42.40 & 35.40 & $23.25^{c}$ & $* *$ \\
\hline & $1 \mathrm{R}$ & 4.00 & 6.00 & 16.20 & 12.40 & $9.65^{d}$ & \\
\hline & Mean & $18.70^{c}$ & $28.05^{b}$ & $41.10^{a}$ & $37.75^{a}$ & $(31.40)$ & \\
\hline
\end{tabular}

-The same letter $(\mathrm{s})$ in each row or column means indicate no significant difference $(P \leq 0.01)$ between factor levels according to Duncan's multiple range test.

+The recommended rate of oxamyl : $0.2 \mathrm{ml} / \mathrm{plant}=48 \mathrm{mg}$ a.i. $/$ plant.

++ The recommended rates of surfactants: $15 \mathrm{ml} / 100 \mathrm{~L}, 5 \mathrm{ml} / 100 \mathrm{~L}$, and $250 \mathrm{ml} / 100 \mathrm{~L}$, respectively for Agrimax-3 $\mathrm{H}^{\circledR}$, Silwet L-7 $7^{\circledR}$ and Sylgard $309^{\circledR}$. 
Table 5. Effect of curative treatment of the combination of Silwet L-77, Sylgard 309 andAgrimax-3H with oxamyl on Meloidogyne incognita nematode parameters (post-application).

\begin{tabular}{|c|c|c|c|c|c|c|c|}
\hline \multirow[b]{2}{*}{ Parameter } & \multirow{2}{*}{$\begin{array}{c}\text { Oxamyl }^{+} \\
\text {application } \\
\text { rate }\end{array}$} & \multicolumn{4}{|c|}{ Surfactants at the recommended rate ${ }^{++}$} & \multirow[b]{2}{*}{ Mean } & \multirow[b]{2}{*}{ Interaction } \\
\hline & & None & $\underset{3 H}{\text { Agrimax- }}$ & $\begin{array}{c}\text { Silwet L- } \\
77\end{array}$ & $\begin{array}{c}\text { Sylgard } \\
309\end{array}$ & & \\
\hline \multirow{3}{*}{$\begin{array}{c}\text { No. of } \\
\text { galls } / 1 \mathrm{~g} \\
\text { root }\end{array}$} & 0 & 24.50 & 22.60 & 22.80 & 23.0 & $23.23^{\mathrm{a}}$ & \multirow{3}{*}{$* *$} \\
\hline & $1 \mathrm{R}$ & 17.40 & 16.0 & 22.80 & 22.20 & $19.60^{\mathrm{b}}$ & \\
\hline & Mean & $20.95^{b}$ & $19.30^{b}$ & $22.80^{\mathrm{a}}$ & $22.60^{\mathrm{a}}$ & (21.41) & \\
\hline \multirow{3}{*}{$\begin{array}{c}\text { No. egg } \\
\text { masses } / 1 \text { g } \\
\text { root }\end{array}$} & 0 & 50.50 & 47.20 & 48.20 & 48.80 & $48.68^{a}$ & \multirow{3}{*}{$* *$} \\
\hline & $1 \mathrm{R}$ & 33.20 & 31.20 & 46.40 & 47.60 & $39.60^{b}$ & \\
\hline & Mean & $41.85^{b}$ & $39.20^{b}$ & $47.30^{a}$ & $48.20^{\mathrm{a}}$ & (44.14) & \\
\hline \multirow{3}{*}{$\begin{array}{l}\text { No. IJs } \\
\text { /100 g soil }\end{array}$} & 0 & 17.25 & 15.0 & 14.60 & 15.80 & $15.66^{a}$ & \multirow{3}{*}{$* *$} \\
\hline & $1 \mathrm{R}$ & 2.40 & 1.0 & 13.60 & 14.80 & $7.95^{b}$ & \\
\hline & Mean & $9.83^{b}$ & $8.00^{b}$ & $14.10^{\mathrm{a}}$ & $15.30^{\mathrm{a}}$ & (11.80) & \\
\hline \multirow{3}{*}{$\begin{array}{c}\text { No. free } \\
\text { eggs } / 100 \\
g\end{array}$} & 0 & 5.25 & 4.0 & 4.20 & 4.80 & $4.56^{a}$ & \multirow{3}{*}{$* *$} \\
\hline & $1 \mathrm{R}$ & 1.40 & 1.0 & 3.40 & 3.40 & $2.30^{b}$ & \\
\hline & Mean & $3.33^{b}$ & $2.50^{b}$ & $3.80^{a}$ & $4.10^{a}$ & (3.43) & \\
\hline
\end{tabular}

The same letter (s) in each row or column means indicates no significant difference $(P \leq 0.01)$ between factor levels according to Duncan's multiple range test.

+ The recommended rate of oxamyl: $0.2 \mathrm{ml} /$ plant $=48 \mathrm{mg}$ a.i./ plant .

++ The recommended rates of surfactants: $15 \mathrm{ml} / 100 \mathrm{~L}, 5 \mathrm{ml} / 100 \mathrm{~L}$, and $250 \mathrm{ml} / 100 \mathrm{~L}$, respectively for Agrimax-3 $\mathrm{H}^{\circledR}$, Silwet L- $77^{\circledR}$ and Sylgard $309^{\circledR}$.

Most review studies focused on protective treatment with nematicides for $M$. incognita control although the benefit of earlier oxamyl application was greater than soon after infection (Wright and Rowland, 1982) and the remarkable reduction percentages for nematode parameters tested "root galls and egg masses" (Elsebae, 1996; El-Sherif et al., 2010; Khalil et al., 2012) to provide adequate nematode control for the first 48-56 days after application but regardless of the application method used, oxamyl dissipated relatively rapid in the field (Giannakou et al., 2005), and oxamyl half-life ranged from 7 to 28 days (Ambrose et al., 2000). As well as, the soil types (clay, sandy loam, and loamy sand) and application rates of oxamyl on the control of $M$. incognita on tomato. Oxamyl was less effective in clay and sandy loam, especially in loamy sand (Abu Elamayem et al., 1984). Based on the above, control efficiency of root-knot nematodes raised with increasing application rate and the volume of applied solution, but decreased with the increase of depth of nematode burial (Lamberti et al., 2002).

Achieving the maximum benefit from pesticides does not come from adjusting the properties of formulation provided to the farmer but through wise and economic a tank mix additive (adjuvant). Some of these additional materials such as Silwet L-77 and Sylgard 309 may increase the immediate efficiency but contribute to the speed of deterioration and disappearance of the oxamyl through increasing wettability and spreading besides, some of these additional materials may enhance the stability and availability of the compound as long as possible, as in the multipurpose adjuvant Agrimax-3H.

\section{REFERENCES}

Abu Elamayem, M.M., El-Shoura, M.Y., El-Khishen, S.A., El-Sebae, A.H., 1984. Efficacy and persistence of certain nematicides in different soils. Beitrage zur tropischen Landwirtschaft und Veterinarmedizin, 22, 171-177. 
Ambrose, E., Haydock, P.P.J., Wilcox, A., 2000. Degradation of the nematicide oxamyl in field conditions. Aspects of Applied Biology, 41-51.

Bird, A.F., 1958. The adult female cuticle and egg sac of the genus Meloidogyne Goeldi, 1887. Nematologica, 3, 205-212.

Castro, E.B., Carbonari, C.A., Velini, E.D., Gomes, G.L.G.C., Belapart, D., 2018. Influence of adjuvants on the surface tension, deposition and effectiveness of herbicides on fleabane plants. Planta Daninha, 36: e018166251. https://doi.org/10.1590/s010083582018360100067

Eisenback, J.D., Triantaphyllou, H.H., 1991. Root-knot nematodes: Meloidogyne species and races. Manual of Agricultural Nematology, 1, 191-274.

El-Ashry, R.M., Ali, A.A.I., ElSobki, A.E.A.M., 2019. Nematicidal properties of three adjuvants for management of southern root-knot nematode, Meloidogyne incognita in vitro and under greenhouse conditions. Journal of Plant Protection and Pathology, 10, 511-519. https://doi.org/10.21608/jppp.2019.64355

Elsebae, A.A., 1996. Rationalization of nematicides in management of root-knot nematode Meloidogyne incognita in plastic greenhouses at North Sinai. Alexandria Journal of Agricultural Research, 41, 191-206.

El-Sherif, A.G., Refaei, A.R., El-Nagar, M.E., Salem, M.M.H., 2010. Impact of certain oilseed cakes or powder in comparison with oxamyl or urea on Meloidogyne incognita infecting eggplant. Archives of Phytopathology and Plant Protection, 43, 88-94. https://doi.org/10.1080/03235400701722103

Finney, D.J., 1971. Probit analysis, $3^{\text {rd }}$ ed. Cambridge University Press. Cambridge, UK.

Giannakou, I.O., Karpouzas, D.G., Anastasiades, I., Tsiropoulos, N.G., Georgiadou, A., 2005. Factors affecting the efficacy of non-fumigant nematicides for controlling root-knot nematodes. Pest Management Science, 61, 961-972. https://doi.org/10.1002/ps.1081

Haq, S., Saxena, S.K., Khan, M.W., 1983. Toxicity of systemic nematicides in relation to larval hatching and mortality or root-knot nematode (Meloidogyne incognita). Indian Journal of Parasitology, 7, 193-194.

Health Canada, 1998. The health and environment handbook for health professionals: health and environment. Ottawa: Health Canada.

Hooper, D.J., 1990. Extraction and processing of plant and soil nematodes, in: Plant parasitic nematodes in subtropical and tropical agriculture. CAB International, Wallingford, UK, pp. 45-68.

Hussey, R.S., Barker, K.R., 1973. Comparison of methods of collecting inocula of Meloidogyne spp., including a new technique. Plant Disease Reporter, 59, 10251028.

Imai, T., Tsuchiya, S., Fujimori, T., 1995. Aphicidal effects of Silwet L-77, organosilicone nonionic surfactant. Applied Entomology and Zoology, 30, 380-382.

Ishibashi, N., Takii, S., 1993. Effects of insecticides on movement, nictation, and infectivity of Steinernema carpocapsae. Journal of Nematology, 25, 204-213.

Jepson, S.B., 1987. Identification of root-knot nematodes (Meloidogyne species)., 1st ed. ed. CAB International, Wallingford, UK.

Jung, W.-J., Jung, S., An, K., Jin, Y., Park, R., Kim, K., Shon, B., Kim, T.-H., 2002. Effect of chitinase-producing Paenibacillus illinoisensis KJA-424 on egg hatching of rootknot nematode (Meloidogyne incognita). Journal of Microbiology and Biotechnology, 12, 865-871. 
Khalil, M.S., Kenawy, A., Gohrab, M.A., Mohammed, E.E., 2012. Impact of microbial agents on Meloidogyne incognita management and morphogenesis of tomato. Journal of Biopesticides, 5, 28-35.

Lamberti, F., D'Addabbo, T., Greco, P., Carella, A., 2002. Efficacy of the liquid formulation of some nematicides. Faculty of Agricultural and Applied Biological Sciences, Ghent University, 67, 699-702.

Maggenti, A.R., Allen, M.W., 1960. The origin of the gelatinous matrix in Meloidogyne. Proc. Helminthol. Society of Washington, 27, 4-10.

Mahmud, M., Wesemael, W., 2014. The importance of the gelatinous matrix for the survival of eggs of Meloidogyne chitwoodi and M. fallax. Doctoral dissertation, Department of Biology, Faculty of Science, Ghent University.

Moens, M., Perry, R.N., Starr, J.L., 2009. Meloidogyne species-a diverse group of novel and important plant parasites. Root-Knot Nematodes, 1, 483.

Narayanan, K.S., Ianniello, R.M., 1996. Superior multipurpose adjuvant system for rainfastness and UV protection. In Pesticide Formulations and Application Systems, 15,168-181.

Narayanan, K.S., Tallon, M., 1997. Solid adjuvant systems - formulations, stability, and efficacy. In Pesticide Formulations and Application Systems, 17,241-256.

Nardo, E., Grewal, P., 2003. Compatibility of Steinernema feltiae (Nematoda: Steinernematidae) with pesticides and plant growth regulators used in glasshouse plant production. Biocontrol Science and Technology, 13, 441-448. https://doi.org/10.1080/0958315031000124495

Ntalli, N.G., Caboni, P., 2012. Botanical nematicides: a review. Biocontrol Science and Technology, 60, 9929-9940. https://doi.org/10.1021/jf303107j

Oka, Y., Koltai, H., Bar-Eyal, M., Mor, M., Sharon, E., Chet, I., Spiegel, Y., 2000. New strategies for the control of plant-parasitic nematodes. Pest Management Science: formerly Pesticide Science, 56, 983-988.

Parker, T., 1993. Multipurpose Agrimax adjuvant system, in: Wilson, B.J., Swarbrick, J.T. (Eds.), Southeastern States of USA. Queensland Weed Society, pp. 73-76.

Peterson, C.A., de Wildt, P.P.Q., Edgington, L.V., 1978. A rationale for the ambimobile translocation of the nematicide oxamyl in plants. Pesticide Biochemistry and Physiology, 8, 1-9. https://doi.org/10.1016/0048-3575(78)90086-X

Pimentel, D., 1995. Amounts of pesticides reaching target pests: environmental impacts and ethics. Journal of Agricultural and environmental Ethics, 8, 17-29.

Ravichandra, N.G., 2014. Horticultural nematology. Springer India. PP. 412.

Sasser, J., Barker, K., Nelson, L., 1975. Correlations of field populations of nematodes with crop growth responses for determining relative involvement of species. Journal of nematology, 7, 193.

Sharma, I.P., Sharma, A., 2015. Effects of initial inoculums levels of Meloidogyne incognita $\mathbf{J}_{2}$ on development and growth of tomato cv. PT-3 under control conditions. African journal of microbiology research, 9, 1376-1380. https://doi.org/10.5897/AJMR2015.7553

Stirling, G., Dullahide, S., Nikulin, A., 1995. Management of lesion nematode (Pratylenchus jordanensis) on replanted apple trees. Australian journal of experimental agriculture, 35, 247-258. 
Sudirman, J.M., 1995. Effect of ammonium ions on egg hatching and second-stage juveniles of Meloidogyne incognita in axenic tomato root culture. Journal of nematology, 27, 346.

Taylor, A., 2003. Nematicides and nematicides-a history. Nematropica, 33, 225-232.

Taylor, A.L., Sasser, J.N., 1978. Biology, identification and control of root-knot nematodes (Meloidogyne species). Dept. of Plant Pathology, North Carolina State University, USA.

Tchounwou, P.B., Ashour, B.A., Moreland-Young, C., Ragheb, D.A., Romeh, A.A., Goma, E.-A., El-Sheikh, S., Lidell, F.P., Ibitayo, O., Assad, J.-C., 2002. Health risk assessment of pesticide usage in Menia El-Kamh Province of Sharkia Governorate in Egypt. International Journal of Molecular Sciences, 3, 1082-1094.

Trinh, Q.P., Le, T.M.L., Nguyen, T.D., Nguyen, H.T., Liebanas, G., Nguyen, T.A.D., 2019. Meloidogyne daklakensis n. sp.(Nematoda: Meloidogynidae), a new root-knot nematode associated with Robusta coffee (Coffea canephora Pierre ex A. Froehner) in the Western Highlands, Vietnam. Journal of helminthology, 93, 242-254.

Wallace, H.R., 1968. The influence of soil moisture on survival and hatch of Meloidogyne javanica. Nematologica, 14, 231-242.

Whitehead, A., Hemming, J., 2008. A Comparison of some quantitative methods of extracting small vermiform nematodes from soil. Annals of Applied Biology, 55, 25-38. https://doi.org/10.1111/j.1744-7348.1965.tb07864.x

Wright, D.J., Blyth, A.R.K., Pearson, P.E., 1980. Behaviour of the systemic nematicide oxamyl in plants in relation to control of invasion and development of Meloidogyne incognita. Annals of Applied Biology, 96, 323-334. https://doi.org/10.1111/j.17447348.1980.tb04783.x

Wright, D.J., Rowland, A.J., 1982. Susceptibility of different developmental stages of the root-knot nematode, Meloidogyne incognita, to the nematicide oxamyl. Annals of Applied Biology,100,521-525.https://doi.org/10.1111/j.1744-7348.1982.tb01418.x

Wright, D.J., Womack, N., 1981. Inhibition of development of Meloidogyne incognita by root and foliar applications of oxamyl. Annals of Applied Biology, 97, 297-302. https://doi.org/10.1111/j.1744-7348.1981.tb05115.x

Zabkiewwicz, J.A., Stevens, P.J.G., 1992. Silwet surfactants have physical and physiological properties which enhance the performance of herbicide spray formulations. Proceedings of The $3^{\text {rd }}$ International Conference on Plant Protection in the Tropics, Genting Highlands, Malaysia. 20-23 March 1990. Malaysian Plant Protection Society.. 


\section{ARABIC SUMMARY}

التأثير المحتمل لمخاليط مبيد الأوكساميل النيماتودي مع المواد المساعدة لمكافحة إصابة نيماتودا تعقد الجذور Meloidogyne incognita

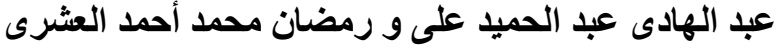

$$
\begin{aligned}
& \text { قسم وقاية النبات ـ كلية الزر اعة - جامعة الزقازيق الزمان }
\end{aligned}
$$

للمو اد المساعدة الداخلة في تجهير ات مستحضرات المبيدات دور هام في تعزيز الخصائص الفيزيائية

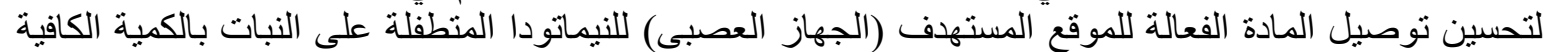

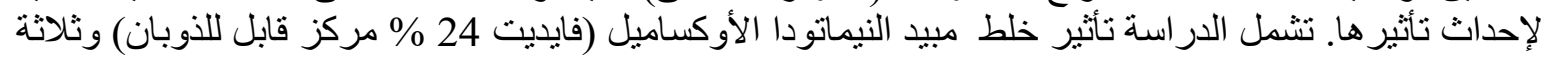

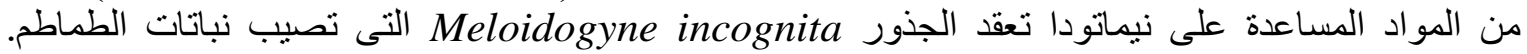

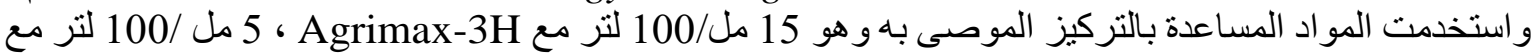

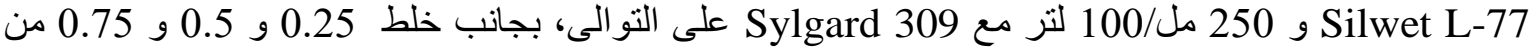
التركيز الموصى به لهذه المو اد المساعدة مع 0.25 و 0.50 و 0.75 من التركيز الموصى به من الأوكساميل (48 ملإر ام مادة فعالة/نبات).

كثفت النتائج عن قدرة المواد اد المساعدة على تثبيط الفقس لكل من كتل البيض و البيض المفرد بنسبة مقدارها

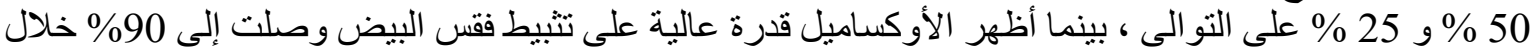

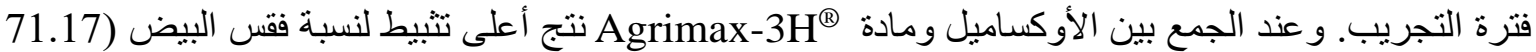

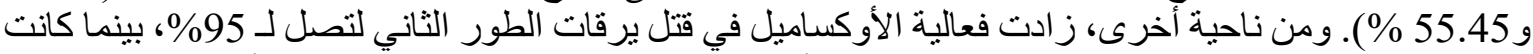

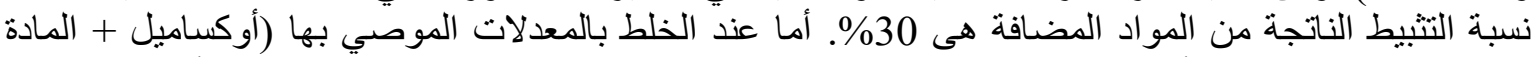

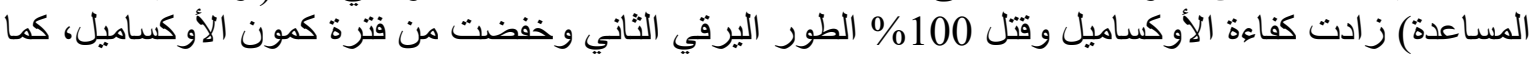

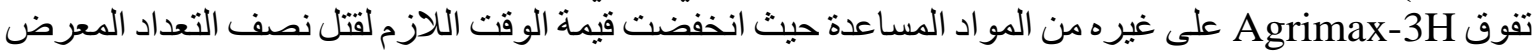

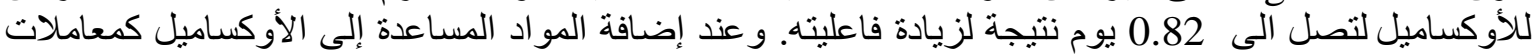

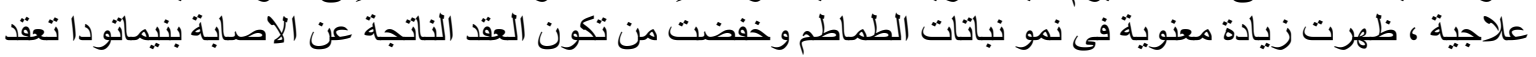

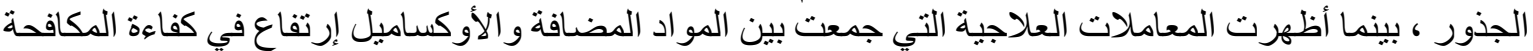
للمعاملات التي جمعت بين الأوكساميل و Agrimax-3H فقط، حيث فاقت في تأثير ها المكافحة الناتجة عن استخدام مستحضر الأوكساميل فقط ولكن بدون فرق معنوي. 